Article

\title{
Bioactive Indolyl Diketopiperazines from the Marine Derived Endophytic Aspergillus versicolor DY180635
}

\author{
Yi Ding, Xiaojing Zhu, Liling Hao, Mengyao Zhao, Qiang Hua and Faliang An *D \\ State Key Laboratory of Bioreactor Engineering, East China University of Science and Technology, \\ 130 Mei Long Road, Shanghai 200237, China; zjzsdy@163.com (Y.D.); 13761041863@163.com (X.Z.); \\ holiday_hao1988@126.com (L.H.); myzhao@ecust.edu.cn (M.Z.); qhua@ecust.edu.cn (Q.H.) \\ * Correspondence: flan2016@ecust.edu.cn; Tel.: +86-21-6425-1185
}

Received: 3 June 2020; Accepted: 25 June 2020; Published: 28 June 2020

\begin{abstract}
Four new indolyl diketopiperazines, aspamides A-E (1-4) and two new diketopiperazines, aspamides $\mathrm{F}-\mathrm{G}$ (5-6), along with 11 known diketopiperazines and intermediates were isolated from the solid culture of Aspergillus versicolor, which is an endophyte with the sea crab (Chiromantes haematocheir). Further chiral high-performance liquid chromatography resolution gave enantiomers $(+)-$ and (-)-4, respectively. The structures and absolute configurations of compounds 1-6 were determined by the comprehensive analyses of nuclear magnetic resonance (NMR), high-resolution mass spectrometry (HR-MS), and electronic circular dichroism (ECD) calculation. All isolated compounds were selected for the virtual screening on the coronavirus 3-chymoretpsin-like protease (Mpro) of Severe Acute Respiratory Syndrome Coronavirus 2 (SARS-CoV-2), and the docking scores of compounds 1-2, 5, 6, 8 and 17 were top among all screened molecules, may be helpful in fighting with Corona Virus Disease-19 (COVID-19) after further studies.
\end{abstract}

Keywords: endophyte fungus; Aspergillus versicolor; diketopiperazines; ECD calculation; enantiomers

\section{Introduction}

Endophytic fungi refer to harmless parasitic fungi that live in the internal organs of plants and animals without causing any adverse reactions. The host provides nutrients for endophytes, and endophytes produce bioactive substances, giving the host an advantage in survival competition [1]. Symbionts coexist with symptomless fish, sponges, algae, and soft corals that grow in a relatively harsh marine environment characterized by high salinity, scarce nutrients, and high osmotic and hydraulic pressures, which provides many environment-specific microorganisms that could coevolve with their hosts by undergoing the rapid and dynamic change of their genomes [2,3]. Thus, endophytic fungi are considered as a treasure trove of unique structural compounds and bioactive metabolites.

Indolyl diketopiperazines (IDKPs), cyclic dipeptides produced by the condensation of L-tryptophan and a second amino acid, were commonly isolated from fungi, especially from the genera Aspergillus and Penicillium [4,5]. IDKPs had drawn considerable attention from synthetic chemists, natural products researchers, and synthetic biologists for decades due to their significant biological activities, such as antiviral [6,7], anticancer [8-10], immunomodulatory [11,12], antioxidant [13], and $\alpha$-glucosidase inhibitory activities [14]. Specifically, the vascular disrupting and tubulin-depolymerizing agent plinabulin, a synthetic analog based on the natural diketopiperazine (DKP) product halimide generated by the marine-derived Aspergillus sp. CNC-139, had entered the last stage of clinical study for the treatment of non-small-cell lung cancer $[15,16]$. Since the first IDKP alkaloid chaetomin isolated from the fungus Chaetomium cochliodes in the early 1940s, a series of DKPs and their biosynthesis clusters were reported [17-22]. In our continuous investigations of novel bioactive agents from the endophytic fungi [23,24], the endophytic strain Aspergillus versicolor DY180635 isolated from 
the sea crab was selected based on the bio-evaluation results. The ethyl acetate extracts of a rice solid culture of $A$. versicolor DY180635 showed $80 \%$ inhibition on the anti-inflammation model of the Propionibacterium acnes-induced THP-1 cells at the concentration of $0.1 \mathrm{mg} / \mathrm{mL}$ [25]. High-performance liquid chromatography (HPLC) analysis of the ethyl acetate extracts indicated the presence of IDKPs with a diode array detector (DAD) through ultraviolet characteristics at $\lambda_{\max } 236,289$, and $336 \mathrm{~nm}$ [26]. Thus, to discover structurally complex and/or bioactive DKPs, the spectroscopic-guided isolation was performed in this research.

Spectroscopic-guided isolation resulted in the identification of four new IDPKs, aspamides A-E (1-4) and two new DPKs, aspamides F-G (5-6), along with 11 known diketopiperazines and intermediates from the ethyl acetate (EtOAc) extracts of the solid culture of $A$. versicolor (Figure 1). The couple of epimers 1-2 were the first samples of brevianamides with an oxygenated aza-acetal structure at the proline motif. All isolated compounds were tested for anti-inflammation in P. acnes-induced THP-1 cells. Unfortunately, none showed active effect. With the appearance and spread of SARS-CoV-2 at the end of 2019, compounds 1-17 were selected for the virtual screening on the 3CL hydrolase (Mpro) of SARS-CoV-2, which had been exploited as a potential drug target to fight COVID-19 [27]. The docking scores of compounds 1-2, 5, 6, 8, and 17 were top among all screened molecules (docking scores: $-5.389,-4.772,-5.146,-4.962,-5.158$ ), which may be helpful in fighting COVID-19 after further studies. Herein, we reported the isolation, structural identification, and bio-evaluation of isolated compounds.

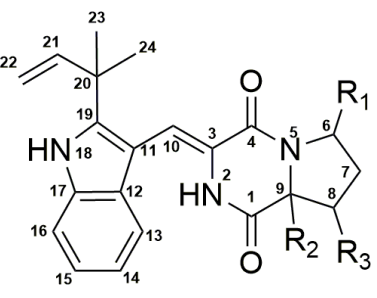

$$
\begin{array}{lll}
\mathrm{R}_{1}=\alpha-\mathrm{OCH}_{2} \mathrm{CH}_{3} & \mathrm{R}_{2}=\alpha-\mathrm{H} & \mathrm{R}_{3}=\mathrm{H} \\
\mathrm{R}_{1}=\beta-\mathrm{OCH}_{2} \mathrm{CH}_{3} & \mathrm{R}_{2}=\alpha-\mathrm{H} & \mathrm{R}_{3}=\mathrm{H} \\
\mathrm{R}_{1}=\mathrm{H} & \mathrm{R}_{2}=O \mathrm{OCH}_{2} \mathrm{CH}_{3} & \mathrm{R}_{3}=\mathrm{H} \\
\mathrm{R}_{1}=\mathrm{H} & \mathrm{R}_{2} \mathrm{R}_{3}=\Delta^{8,9} & \\
\mathrm{R}_{1}=\mathrm{H} & \mathrm{R}_{2}=\mathrm{OH} & \mathrm{R}_{3}=\mathrm{H} \\
\mathrm{R}_{1}=\mathrm{H} & \mathrm{R}_{2}=\beta-\mathrm{H} & \mathrm{R}_{3}=\mathrm{H} \\
\mathrm{R}_{1}=\mathrm{H} & \mathrm{R}_{2}=\mathrm{OH} & \mathrm{R}_{3}=\mathrm{OH}
\end{array}
$$<smiles>C=CC(C)(C)c1[nH]c2ccccc2c1/C=C1\NC(=O)[C@@H]2C[C@@H](O)CN2C1=O</smiles>

3

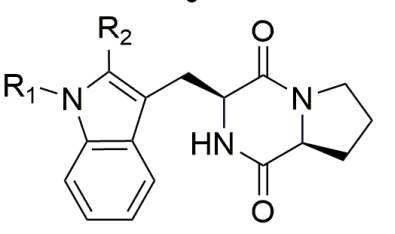

$$
\begin{array}{ll}
11 \mathrm{R}_{1}=\mathrm{H} & \mathrm{R}_{2}=\mathrm{H} \\
12 & \mathrm{R}_{1}=\mathrm{H} \\
13 & \mathrm{R}_{1}=\mathrm{R}-\mathrm{R}=- \\
\mathrm{R}_{2}=\mathrm{H}
\end{array}
$$

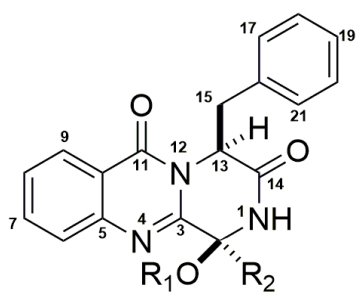

$5 \quad \mathrm{R}_{1}=\mathrm{H} \quad \mathrm{R}_{2}=\mathrm{CH}_{3}$ $6 \quad \mathrm{R}_{1}=\mathrm{H} \quad \mathrm{R}_{2}=\mathrm{CH}_{2} \mathrm{CH}_{3}$ $16 \mathrm{R}_{1}=\mathrm{O} \quad \mathrm{R}_{2}=\mathrm{O}$ $17 \mathrm{R}_{1}=\mathrm{H} \quad \mathrm{R}_{2}=\mathrm{H}$

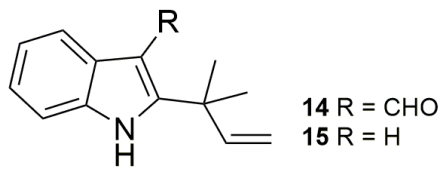

Figure 1. Structures of compounds 1-17.

\section{Results and Discussion}

The EtOAc extract of the rice solid culture of A. versicolor DY180635 was fractionated by column chromatography (CC) on macroporous adsorbent resin, silica gel, and octadecyl silane (ODS), as well as by preparative HPLC, to afford 15 DKPS and two intermediates. Six new DKPs, named as aspamides A-F (1-6), were determined by comprehensive spectroscopic analysis including ${ }^{1} \mathrm{H}$ nuclear magnetic resonance (NMR), ${ }^{13} \mathrm{C}$ NMR, HSQC, heteronuclear multiple bond correlation (HMBC), rotating frame Overhauser effect spectroscopy (ROESY), and high resolution electrospray mass spectrometry (HRESIMS) spectra. By comparing the NMR and ESIMS data to the reported literatures in detail, 11 known compounds were determined as brevianamides $K, N$, and $M(7,16,17)[28]$, brevianamide $\mathrm{Q}$ (8) [29], brevianamides V, U (9-10) [20], brevianamide F (11) [30], deoxybrevianamide E (12) [31], N-Prenyl-cyclo-L-tryptophyl-L-proline (13) [32], 2-(2-methyl-3-en-2-yl)-1H-indole-3-carbaldehyde (14) [33], and 2-(1,1-Dimethyl-allyl)-1H-indol-3-ylmercuric acetate (15) [34]. Herein, the details of the isolation, structural elucidation of these new compounds, and their bioactivities are described. 
Aspamide A (1) was isolated as a yellowish powder. The UV spectrum with $\lambda_{\max }(\log \varepsilon)$ in methanol at 200 (6.13), 224 (6.13), 284 (5.46), and 341 (5.68) nm was indicative of indole functionality with an extended conjugation [26]. Its molecular formula was determined as $\mathrm{C}_{23} \mathrm{H}_{27} \mathrm{~N}_{3} \mathrm{O}_{3}$ on the basis of high-resolution ESIMS $\left(\mathrm{m} / z 394.2117[\mathrm{M}+\mathrm{H}]^{+}\right.$, calcd. for $\left.\mathrm{C}_{23} \mathrm{H}_{28} \mathrm{~N}_{3} \mathrm{O}_{3}, 394.2125\right)$ and ${ }^{13} \mathrm{C}$ NMR data, requiring 12 degrees of unsaturation. The ${ }^{1} \mathrm{H} N M R,{ }^{13} \mathrm{C} N M R$, and heteronuclear multiple quantum correlation (HMQC) spectra (Table 1 and Figure S3 in Supporting Information) showed three methyl groups $\left(\delta_{\mathrm{C}} 27.4, \delta_{\mathrm{H}} 1.45 ; \delta_{\mathrm{C}} 27.8, \delta_{\mathrm{H}} 1.49 ; \delta_{\mathrm{C}} 15.2, \delta_{\mathrm{H}} 1.13\right)$, three sp ${ }^{3}$ methylenes (including one oxygenated methylene) $\left(\delta_{\mathrm{C}} 29.6, \delta_{\mathrm{H}} 1.75, \delta_{\mathrm{H}} 1.97 ; \delta_{\mathrm{C}} 25.9, \delta_{\mathrm{H}} 2.13, \delta_{\mathrm{H}} 2.27 ; \delta_{\mathrm{C}} 63.6, \delta_{\mathrm{H}} 3.65\right)$, two sp ${ }^{3}$ methine carbon signals (including one oxygen-bearing carbon) $\left(\delta_{\mathrm{C}} 56.5, \delta_{\mathrm{H}} 4.57 ; \delta_{\mathrm{C}} 86.7, \delta_{\mathrm{H}} 5.59\right)$, six $\mathrm{sp}^{2}$ methines, one $\mathrm{sp}^{2}$ methylene, seven $\mathrm{sp}^{2}$, and one $\mathrm{sp}^{3}$ non-protonated carbon. The NMR data and UV absorptions were close to those of brevianamide $\mathrm{V}$ [20], with the exception that there was an additional oxygenated aza-acetal structure located at the proline motif $\left(\delta_{\mathrm{C}} 86.7, \delta_{\mathrm{H}} 5.59 ; \delta_{\mathrm{C}} 63.6\right.$, $\delta_{\mathrm{H}} 3.65 ; \delta_{\mathrm{C}} 15.2$, and $\left.\delta_{\mathrm{H}} 1.13\right)$.

Further information about the structure was derived from heteronuclear multiple bond correlation (HMBC) spectra analyses (Figure S4). The key HMBC correlations (Figure 2A) from $\mathrm{OCH}_{2} \mathrm{CH}_{3}-6$ $\left(\delta_{\mathrm{H}} 3.65\right)$ to $\mathrm{C}-6\left(\delta_{\mathrm{C}} 86.7\right), \mathrm{H}-6\left(\delta_{\mathrm{H}} 5.59\right)$ to $\mathrm{C}-9\left(\delta_{\mathrm{C}} 56.5\right), \mathrm{H}-9\left(\delta_{\mathrm{H}} 4.57\right)$ to $\mathrm{C}-8\left(\delta_{\mathrm{C}} 25.9\right)$ and C-1 $\left(\delta_{\mathrm{C}} 165.9\right)$, and $\mathrm{H}-8 \alpha\left(\delta_{\mathrm{H}} 2.27\right)$ to $\mathrm{C}-9$ were observed. These data suggested that an oxethyl group was located at C-6 and confirmed the oxygenated aza-acetal structure at the proline motif, which was previous unpresented in the brevianamide analogues. Thus, the planar structure of $\mathbf{1}$ was determined as shown in Figure 1.

In order to determine the relative configuration of $\mathbf{1}$, the rotating frame Overhauser effect spectroscopy (ROESY, Figure S5) experiment was performed. The ROESY correlation (Figure 2B) between NH-2 $\left(\delta_{\mathrm{H}} 9.01\right)$ and $\mathrm{H}-13\left(\delta_{\mathrm{H}} 7.29\right)$ revealed the $Z$ configuration about $\Delta^{3,10}$, and the ROESY signals between $\mathrm{H}-8 \beta\left(\delta_{\mathrm{H}} 2.13\right)$ and $\mathrm{H}-6$, and between $\mathrm{H}-8 \alpha\left(\delta_{\mathrm{H}} 2.27\right)$ and $\mathrm{H}-9$ suggested that $\mathrm{H}-6$ and $\mathrm{H}-9$ were trans form. The absolute configuration of 1 was assigned as $(6 R, 9 S)$ by comparing the experimental and calculated electronic circular dichroism (ECD) values obtained using Time-dependent Density functional theory (TD-DFT) at the B3LYP/6-31+g (d, p) level (Figure 2C).
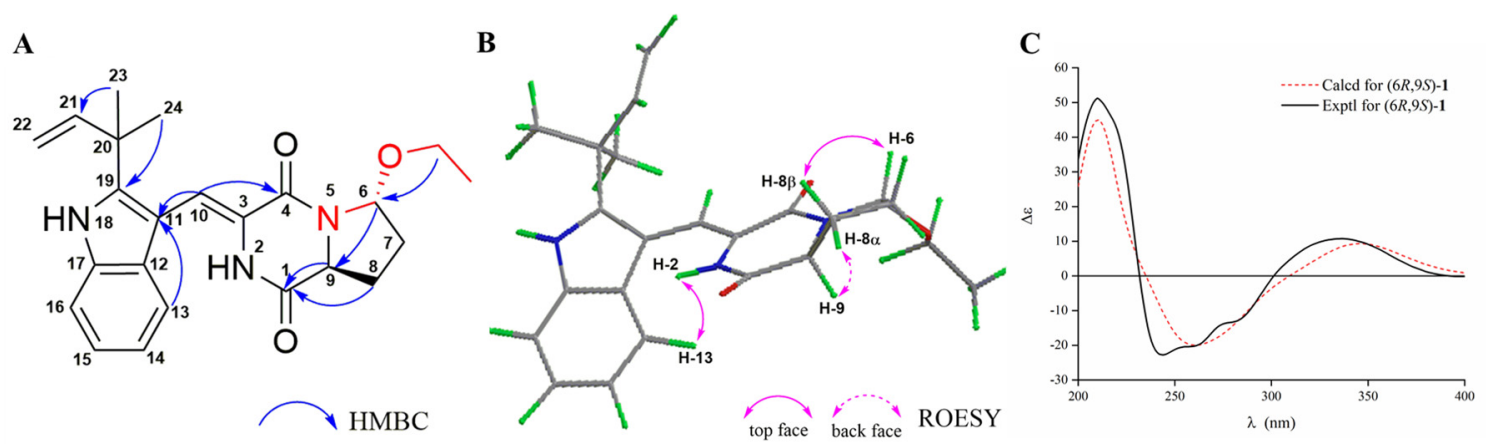

Figure 2. The key heteronuclear multiple bond correlation (HMBC) (A) and rotating frame Overhauser effect spectroscopy (ROESY) (B) correlations, and experimental and calculated electronic circular dichroism (ECD) spectra (C) of compound $\mathbf{1}$.

Aspamide B (2) was obtained as a yellowish powder. Its molecular formula was determined as $\mathrm{C}_{23} \mathrm{H}_{27} \mathrm{~N}_{3} \mathrm{O}_{3}$ on the basis of HRESIMS $\left(m / z 394.2120[\mathrm{M}+\mathrm{H}]^{+}\right.$, calcd. for $\left.\mathrm{C}_{23} \mathrm{H}_{28} \mathrm{~N}_{3} \mathrm{O}_{3}, 394.2125\right)$ and ${ }^{13} \mathrm{C}$ NMR data, corresponding to 12 degrees of unsaturation. By comparing the ${ }^{1} \mathrm{H},{ }^{13} \mathrm{C}$, and HMQC data (Table 1, Figure S11) of $\mathbf{2}$ with those of $\mathbf{1}$, it was discovered that $\mathbf{2}$ possessed the identical planar structure as that of $\mathbf{1}$. Further analyses of the 2D NMR data of 2, the key HMBC correlations from H-6 $\left(\delta_{\mathrm{H}} 5.35\right)$ to $\mathrm{OCH}_{2} \mathrm{CH}_{3}-6\left(\delta_{\mathrm{C}} 64.3\right)$ and $\mathrm{C}-9\left(\delta_{\mathrm{C}} 58.7\right)$, as well as $\mathrm{H}-9\left(\delta_{\mathrm{H}} 4.44\right)$ to $\mathrm{C}-1\left(\delta_{\mathrm{C}} 166.8\right)$ revealed that the oxethyl group was located at $\mathrm{C}-6$. Furthermore, the difference between $\mathrm{H}-6\left(\delta_{\mathrm{H}} 5.35\right.$, $\mathrm{dd}, J=2.8,1.7 \mathrm{~Hz})$ in 2 and $\mathrm{H}-6\left(\delta_{\mathrm{H}} 5.59, \mathrm{dd}, J=5.7,1.7 \mathrm{~Hz}\right)$ in 1 indicated that 2 was the C-6 epimer of $\mathbf{1}$. Furthermore, the same ECD cotton effects (Figure 3C) of $\mathbf{2}$ compared to $\mathbf{1}$ indicated that the 
absolute configuration of C-9 in $\mathbf{2}$ was consistent with that in $\mathbf{1}$. This result suggested that within the used spectral window, the ECD cotton effects were mainly caused by the chiral center of C-9 in both compounds $\mathbf{1}$ and 2, and it could also be confirmed by the experimental ECD data of (+)-brevianamide $\mathrm{V}$ and (-)-brevianamide V [35]. Thus, the absolute configuration of compound 2 was ascertained as $(6 S, 9 S)$.

Aspamide C (3) was obtained as a yellowish powder. The molecular formula was established as $\mathrm{C}_{21} \mathrm{H}_{23} \mathrm{~N}_{3} \mathrm{O}_{3}$ by HRESIMS $\left(\mathrm{m} / z 366.1807[\mathrm{M}+\mathrm{H}]^{+}\right.$, calcd. for $\left.\mathrm{C}_{21} \mathrm{H}_{24} \mathrm{~N}_{3} \mathrm{O}_{3}, 366.1812\right)$, indicating 12 degrees of unsaturation. The UV and NMR spectra were very similar to those of compound 1 . A comparison of the NMR data for 3 with 1, together with characteristic HMBC signals (Figure 3A), suggested that the oxethyl group was replaced by a second $\mathrm{OH}$ in 3 . However, the $\mathrm{OH}$ group was not located at C-6, which was the same as the 1, to form the aza-acetal structure for which the chemical shift of oxygenated methylene $\left(\delta_{C} 66.6\right)$ was far below the shift of C-6 $\left(\delta_{C} 86.7\right)$ in 1 . Thus, the second $\mathrm{OH}$ was distributed to C-7, and the planar structure of 3 was determined as shown in Figure 1. The ROESY correlation (Figure S20) between NH-2 $\left(\delta_{\mathrm{H}} 8.93\right)$ and $\mathrm{H}-13\left(\delta_{\mathrm{H}} 7.29\right)$ confirmed the cis form of the double bond between C-3 and C-10. Furthermore, the ROESY signals (Figure $3 B$ ) between $\mathrm{H}-8 \beta\left(\delta_{\mathrm{H}} 1.98\right)$ and $\mathrm{H}-7\left(\delta_{\mathrm{H}} 4.35\right)$, and between $\mathrm{H}-8 \alpha\left(\delta_{\mathrm{H}} 2.12\right)$ and $\mathrm{H}-9\left(\delta_{\mathrm{H}} 4.65\right)$ revealed that $\mathrm{H}-7$ and $\mathrm{H}-9$ were trans form. Finally, the absolute configuration of 3 was determined as $(7 R, 9 S)$ by comparison of the experimental ECD curve of $\mathbf{3}$ with that of $\mathbf{1}$ (Figure 3C).

A

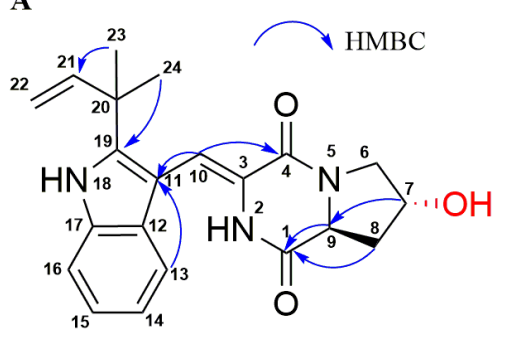

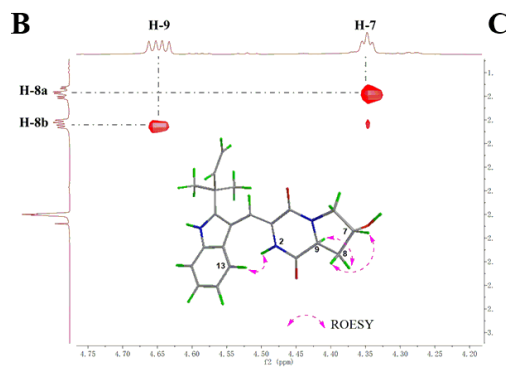

Figure 3. The key HMBC correlations (A) and partial enlarged view of ROESY spectra (B) of 3, and experimental ECD spectra (C) of compounds 1-3.

Table 1. ${ }^{1} \mathrm{H}(600 \mathrm{MHz})$ and ${ }^{13} \mathrm{C}(150 \mathrm{MHz})$ NMR data of $\mathbf{1}-\mathbf{3}$ in DMSO- $d_{6}$.

\begin{tabular}{|c|c|c|c|c|c|c|}
\hline \multirow{2}{*}{ No. } & \multirow[b]{2}{*}{$\delta_{\mathrm{C}}$} & 1 & \multicolumn{3}{|c|}{2} & \multirow{2}{*}{$\frac{3}{\delta_{\mathrm{H}}, \text { Mult. }(J \text { in Hz})}$} \\
\hline & & $\delta_{\mathrm{H}}$, Mult. $(J$ in $\mathrm{Hz})$ & $\delta_{\mathrm{C}}$ & $\delta_{\mathrm{H}}$, Mult. $(J$ in $\mathrm{Hz})$ & $\delta_{\mathrm{C}}$ & \\
\hline 1 & 165.9 & - & 166.8 & - & 166.2 & - \\
\hline 2 & - & $9.01, \mathrm{~s}$ & - & $9.43, \mathrm{~s}$ & - & $8.93, \mathrm{~s}$ \\
\hline 3 & 125.3 & - & 125.9 & - & 126.2 & - \\
\hline 4 & 158.9 & - & 161.1 & - & 158.4 & - \\
\hline $6 a$ & 86.7 & $5.59, \mathrm{dd}(5.7,1.7)$ & 85.4 & $5.35, \mathrm{dd}(2.8,1.7)$ & 54.4 & $3.32, \mathrm{~m}$ \\
\hline $6 b$ & - & - & - & - & - & $3.75, \mathrm{dd}(12.7,4.5)$ \\
\hline $7 a$ & 29.6 & $\begin{array}{c}1.75, \text { dddd }(13.4, \\
8.4,5.0,1.7)\end{array}$ & 30.7 & $1.92, \mathrm{~m}$ & 66.6 & $4.35, \mathrm{t}(4.5)$ \\
\hline $7 \mathrm{~b}$ & & $1.97, \mathrm{~m}$ & & - & & \\
\hline $8 a$ & 25.9 & $\begin{array}{l}\text { 2.13, dddd (12.2, } \\
9.7,6.7,5.0)\end{array}$ & 24.5 & $1.92, \mathrm{~m}$ & 37.6 & $\begin{array}{l}\text { 1.98, ddd (12.7, } \\
11.5,4.5)\end{array}$ \\
\hline $8 b$ & & $2.27, \mathrm{~m}$ & & $2.10, \mathrm{~m}$ & & 2.12, dd $(12.7,6.0)$ \\
\hline 9 & 56.5 & $4.57, \mathrm{dd}(8.9,6.7)$ & 58.7 & $4.44, \mathrm{~m}$ & 57.0 & $4.65, \mathrm{dd}(11.5,6.0)$ \\
\hline 10 & 111.9 & $6.98, \mathrm{~s}$ & 113.2 & $7.05, \mathrm{~s}$ & 110.7 & $6.92, \mathrm{~s}$ \\
\hline 11 & 103.9 & - & 104.3 & - & 103.8 & - \\
\hline 12 & 125.9 & - & 125.8 & - & 126.0 & - \\
\hline 13 & 119.6 & $7.29, \mathrm{~d}(8.0)$ & 119.7 & $7.23, \mathrm{~d}(8.0)$ & 119.4 & $7.29, \mathrm{~d}(8.0)$ \\
\hline 14 & 119.4 & $6.99, \mathrm{~m}$ & 119.3 & $\begin{array}{l}6.99, \text { ddd }(8.0, \\
7.0,1.2)\end{array}$ & 119.3 & $7.00, \mathrm{~m}$ \\
\hline
\end{tabular}


Table 1. Cont.

\begin{tabular}{|c|c|c|c|c|c|c|}
\hline \multirow{2}{*}{ No. } & \multirow[b]{2}{*}{$\delta_{\mathrm{C}}$} & 1 & \multicolumn{3}{|c|}{2} & \multirow{2}{*}{$\frac{3}{\delta_{\mathrm{H}}, \text { Mult. }(J \text { in } \mathrm{Hz})}$} \\
\hline & & $\delta_{\mathrm{H}}$, Mult. $(J$ in $\mathrm{Hz})$ & $\delta_{\mathrm{C}}$ & $\delta_{\mathrm{H}}$, Mult. $(J$ in $\mathrm{Hz})$ & $\delta_{\mathrm{C}}$ & \\
\hline 15 & 120.7 & $\begin{array}{l}7.08 \text {, ddd }(8.0, \\
7.0,1.2)\end{array}$ & 120.7 & $\begin{array}{l}\text { 7.07, ddd (8.0, } \\
7.0,1.2)\end{array}$ & 120.7 & $\begin{array}{l}7.08, \text { ddd }(8.0, \\
7.0,1.2)\end{array}$ \\
\hline 16 & 111.5 & $7.41, \mathrm{~d}(8.0)$ & 111.6 & $7.41, \mathrm{~m}$ & 111.4 & $7.41, \mathrm{~d}(8.0)$ \\
\hline 17 & 135.1 & - & 135.1 & - & 135.1 & - \\
\hline 18 & & $11.06, \mathrm{~s}$ & - & $11.06, \mathrm{~s}$ & - & $11.03, \mathrm{~s}$ \\
\hline 19 & 144.3 & - & 144.7 & - & 144.0 & - \\
\hline 20 & 39.0 & - & 39.1 & - & 39.0 & - \\
\hline 21 & 145.1 & $6.07, \mathrm{dd}(17.4,10.5)$ & 145.1 & $6.09, \mathrm{dd}(17.1,10.8)$ & 145.2 & $6.08, \mathrm{dd}(17.3,10.5)$ \\
\hline 22 & 111.7 & $5.05, \mathrm{~m}$ & 111.7 & $5.06, \mathrm{~m}$ & 111.6 & $5.04, \mathrm{~m}$ \\
\hline 23 & 27.4 & $1.45, \mathrm{~s}$ & 27.5 & $1.47, \mathrm{~s}$ & 27.4 & $1.46, \mathrm{~s}$ \\
\hline 24 & 27.8 & $1.49, \mathrm{~s}$ & 27.9 & $1.51, \mathrm{~s}$ & 27.7 & $1.50, \mathrm{~s}$ \\
\hline \multirow[t]{2}{*}{ 6-OEt } & 63.6 & $3.65, \mathrm{~m}$ & 64.3 & $3.60, \mathrm{~m}$ & - & - \\
\hline & 15.2 & $1.13, \mathrm{t}(7.1)$ & 15.4 & $1.09, \mathrm{t}(7.1)$ & - & - \\
\hline
\end{tabular}

The racemic $( \pm$ )-aspamide D (4) was isolated as colorless gum with the molecular formula of $\mathrm{C}_{23} \mathrm{H}_{27} \mathrm{~N}_{3} \mathrm{O}_{3}$ from an HRESIMS peak at $m / z 394.2120[\mathrm{M}+\mathrm{H}]^{+}$(calcd. for $\mathrm{C}_{23} \mathrm{H}_{28} \mathrm{~N}_{3} \mathrm{O}_{3}, 394.2125$ ). Its NMR data and UV absorption were similar to compound 1. Comparing to 1, the major change was that two $\mathrm{sp}^{3}$ methines were replaced by one $\mathrm{sp}^{3}$ methylene and one $\mathrm{sp}^{3}$ non-protonated carbon, suggesting that the oxethyl group was connected to $\mathrm{C}-9$ rather to the $\mathrm{C}-6$. Additionally, the key HMBC signals (Figure 4$)$ from $\mathrm{OCH}_{2} \mathrm{CH}_{3}-9\left(\delta_{\mathrm{H}} 3.53\right)$ to $\mathrm{C}-9\left(\delta_{\mathrm{C}} 91.0\right), \mathrm{H}-6\left(\delta_{\mathrm{H}} 3.62\right)$ to $\mathrm{C}-4\left(\delta_{\mathrm{C}} 159.4\right)$ and $\mathrm{C}-9$, and $\mathrm{H}-8 \mathrm{a}\left(\delta_{\mathrm{H}} 2.02\right)$ to $\mathrm{C}-1\left(\delta_{\mathrm{C}} 163.1\right)$ confirmed the aforementioned planar structure. There was no Cotton effect observed on its ECD spectra (Figure S29), which in accordance with the racemic ( \pm )-brevianamide $X[35]$, indicating that 4 might be a pair of enantiomers. Furthermore, the chiral HPLC resolution of $\mathbf{4}$ contributed to the separation of a pair of enantiomers (+)-4 and (-)-4, which exhibited nearly mirror-image ECD spectra (Figure 5). The absolute configurations of (+)-4 and (-)-4 were discriminably determined as $9 R$ and $9 S$ by comparing the experimental and calculated ECD data obtained using TD-DFT at the B3LYP/6-31+g $(\mathrm{d}, \mathrm{p})$ level (Figure 5). Correspondingly, we named (+)-4 and (-)-4 as (+)-aspamide $\mathrm{D}$ and (-)-aspamide $\mathrm{D}$, respectively.

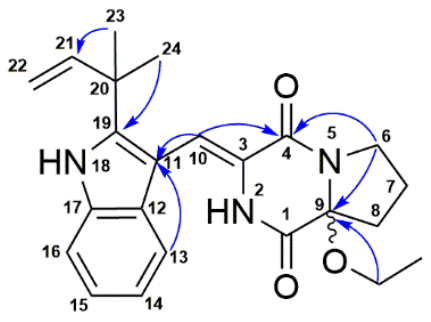

4

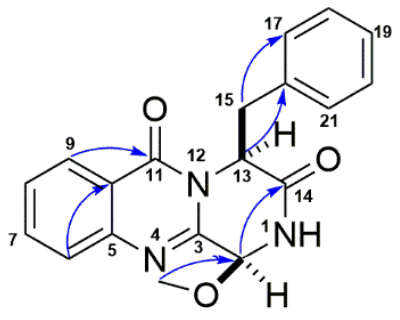

5

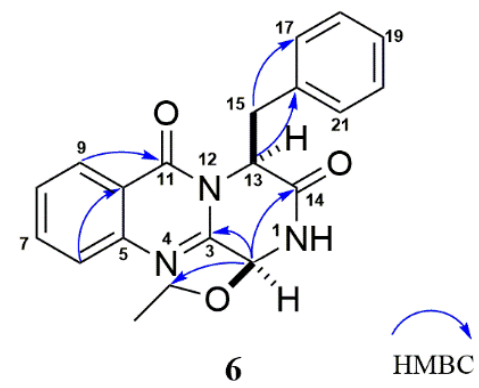

6
$\mathrm{HMBC}$

Figure 4. The key HMBC correlations of compounds 4-6.

Aspamide F (5) was obtained as a brown powder with the molecular formula of $\mathrm{C}_{19} \mathrm{H}_{17} \mathrm{~N}_{3} \mathrm{O}_{3}$ from an HRESIMS peak at $m / z 336.1336[\mathrm{M}+\mathrm{H}]^{+}$(calcd. for $\mathrm{C}_{19} \mathrm{H}_{18} \mathrm{~N}_{3} \mathrm{O}_{3}, 336.1343$ ), requiring 13 indices of hydrogen deficiency. The ${ }^{1} \mathrm{H}$ NMR, ${ }^{13} \mathrm{C}$ NMR, and HMQC spectra (Table 2 and Figure S35) suggested the presence of one oxygenated methyl group, one $\mathrm{sp}^{3}$ methylene, two $\mathrm{sp}^{3}$ methines carbon signals (including one oxygen-bearing carbon), nine $\mathrm{sp}^{2}$ methines, and six $\mathrm{sp}^{2}$ non-protonated carbons. These NMR data of 5 were similar to those of brevianamide M [28], except for the different chemical shifts for C-2 and C-3 due to the presence of a methoxy at C-2 in 5, implying that 5 was an analogue of brevianamide $\mathrm{M}$ with a methoxy at $\mathrm{C}-2$. Additionally, the key HMBC correlations (Figure 4) from $\mathrm{OCH}_{3}-2\left(\delta_{\mathrm{H}} 3.53\right)$ to $\mathrm{C}-2\left(\delta_{\mathrm{C}} 83.9\right)$, from $\mathrm{H}-2\left(\delta_{\mathrm{H}} 5.27\right)$ to $\mathrm{C}-3\left(\delta_{\mathrm{C}} 146.9\right) / \mathrm{C}-14\left(\delta_{\mathrm{C}} 170.0\right)$, and from $\mathrm{H}-13$ 
$\left(\delta_{\mathrm{H}} 5.53\right)$ to $\mathrm{C}-15\left(\delta_{\mathrm{C}} 40.0\right) / \mathrm{C}-16\left(\delta_{\mathrm{C}} 135.9\right)$ confirmed the planner structure of 5 as shown in Figure 4. The absolute configuration of 5 was determined as $(2 S, 13 S)$ via comparing the ECD curve (Figure 6$)$ of 5 with the brevianamide M (17).

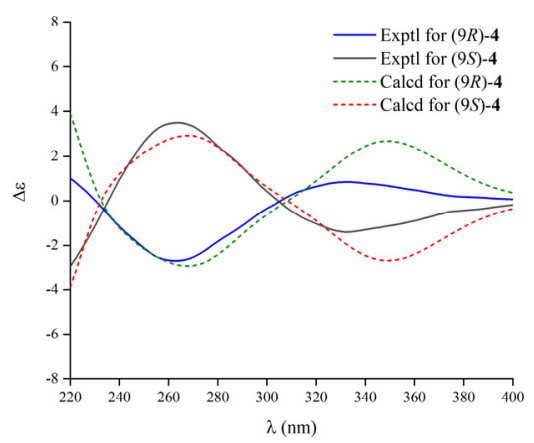

Figure 5. Experimental and calculated ECD spectra of 4.

Table 2. ${ }^{1} \mathrm{H}(600 \mathrm{MHz})$ and ${ }^{13} \mathrm{C}(150 \mathrm{MHz}) \mathrm{NMR}$ data of 4-6 (4 in DMSO- $d_{6}, 5-6$ in $\left.\mathrm{CDCl}_{3}\right)$.

\begin{tabular}{|c|c|c|c|c|c|c|}
\hline \multirow{2}{*}{ No. } & \multirow[b]{2}{*}{$\delta$} & \multirow{2}{*}{$\frac{4}{\delta_{\mathrm{H}}, \text { Mult. }(J \text { in } \mathrm{Hz})}$} & \multicolumn{3}{|c|}{5} & \multirow{2}{*}{$\frac{6}{\delta_{\mathrm{H}}, \text { Mult. }(J \text { in } \mathrm{Hz})}$} \\
\hline & & & $\delta_{\mathrm{C}}$ & $\delta_{\mathrm{H}}$, Mult. $(J$ in $\mathrm{Hz})$ & $\delta_{\mathrm{C}}$ & \\
\hline 1 & 163.1 & - & - & - & - & - \\
\hline 2 & - & $9.43, \mathrm{~s}$ & 83.9 & $5.27, \mathrm{~d}(4.7)$ & 78.3 & $6.40, \mathrm{~d}(4.3)$ \\
\hline 3 & 125.5 & - & 146.9 & - & 151.1 & - \\
\hline 4 & 159.4 & - & - & - & & - \\
\hline 5 & - & - & 146.7 & - & 139.0 & - \\
\hline 6 & 45.1 & $3.62, \mathrm{dd}(8.6,5.8)$ & 127.8 & $7.74, \mathrm{~d}(8.0)$ & 122.9 & $8.23, \mathrm{~d},(8.0)$ \\
\hline $\begin{array}{l}7 \mathrm{a} \\
7 \mathrm{~b}\end{array}$ & 19.5 & $\begin{array}{l}1.92, \mathrm{~m} \\
1.96, \mathrm{~m}\end{array}$ & 134.9 & $7.79, \mathrm{t}(8.0)$ & 136.7 & $7.91, \mathrm{t}(8.0)$ \\
\hline $\begin{array}{l}8 \mathrm{a} \\
8 \mathrm{~b}\end{array}$ & 32.4 & $\begin{array}{l}2.02, \mathrm{~m} \\
2.33, \mathrm{~m}\end{array}$ & 128.0 & $7.53, \mathrm{t}(8.0)$ & 129.7 & $7.66, \mathrm{t}(8.0)$ \\
\hline 9 & 91.0 & - & 127.0 & $8.24, \mathrm{~d}(8.0)$ & 127.9 & $8.23, \mathrm{~d},(8.0)$ \\
\hline 10 & 112.7 & $7.02, \mathrm{~s}$ & 120.8 & - & 119.1 & - \\
\hline 11 & 103.9 & - & 160.3 & - & 157.4 & - \\
\hline 12 & 126.3 & - & - & - & - & - \\
\hline 13 & 119.1 & $7.21, \mathrm{~d}(8.0)$ & 57.4 & $5.53, \mathrm{dd}(8.8,6.5)$ & 58.1 & $5.54, \mathrm{t}(7.8)$ \\
\hline 14 & 119.0 & $7.00, \mathrm{~m}$ & 170.0 & - & 167.6 & - \\
\hline 15 & 120.7 & $7.09, \mathrm{~m}$ & 40.0 & $3.43, \mathrm{~m}$ & 39.9 & $3.48, \mathrm{~m}$ \\
\hline 16 & 111.6 & $7.43, \mathrm{~d}(8.0)$ & 135.9 & - & 134.9 & - \\
\hline 17 & 135.1 & - & 129.8 & $7.29, \mathrm{~m}$ & 129.7 & $7.24, \mathrm{~m}$ \\
\hline 18 & & $11.10, \mathrm{~s}$ & 128.6 & $7.28, \mathrm{~m}$ & 128.8 & $7.24, \mathrm{~m}$ \\
\hline 19 & 144.4 & - & 127.0 & $7.24, \mathrm{~m}$ & 127.7 & $7.20, \mathrm{~m}$ \\
\hline 20 & 39.0 & - & 128.6 & $7.28, \mathrm{~m}$ & 128.8 & $7.24, \mathrm{~m}$ \\
\hline 21 & 145.2 & $\begin{array}{c}6.09 \text {, ddd (17.1, } \\
10.8,1.6)\end{array}$ & 129.8 & $7.29, \mathrm{~m}$ & 129.7 & $7.24, \mathrm{~m}$ \\
\hline 22 & 111.7 & $5.06, \mathrm{~m}$ & - & - & - & - \\
\hline 23 & 27.4 & $1.47, \mathrm{~s}$ & - & - & - & - \\
\hline 24 & 27.8 & $1.50, \mathrm{~s}$ & - & - & - & - \\
\hline 9-OEt & 59.2 & $3.53, \mathrm{qd}(7.0,3.9)$ & - & - & - & - \\
\hline- & 15.2 & $1.22, \mathrm{td}(7.0,1.5)$ & - & - & - & - \\
\hline \multirow{2}{*}{$\begin{array}{l}\text { 2-OMe/ } \\
\text { 2-OEt }\end{array}$} & - & - & 56.0 & $3.53, \mathrm{~s}$ & 66.2 & $\begin{array}{l}4.04, \mathrm{dt}(9.0,7.0) \\
4.11, \mathrm{dt}(9.0,7.0)\end{array}$ \\
\hline & - & - & - & - & 15.4 & $1.35, \mathrm{t}(7.0)$ \\
\hline
\end{tabular}

Aspamide G (6) was isolated as a brown powder. The molecular formula was determined as $\mathrm{C}_{20} \mathrm{H}_{19} \mathrm{~N}_{3} \mathrm{O}_{3}$ by HRESIMS ( $m / z 350.1498[\mathrm{M}+\mathrm{H}]^{+}$, calcd. for $\left.\mathrm{C}_{20} \mathrm{H}_{20} \mathrm{~N}_{3} \mathrm{O}_{3}, 350.1499\right)$, which was 14 Dalton more than 5 . The ${ }^{13} \mathrm{C}$ NMR data of 6 showed a close resemblance to those of 5 , except for 
an additional oxygenated $\mathrm{sp}^{3}$ methylene, suggesting that there was an ethoxy group located at $\mathrm{C}-2$ in 6. The key HMBC signal (Figure 4$)$ from $\mathrm{H}-2\left(\delta_{\mathrm{H}} 6.40\right)$ to $\mathrm{OCH}_{2}-2\left(\delta_{\mathrm{C}} 66.2\right)$ verified that 6 was an analogue of brevianamide M (17) with an ethoxy motif at C-2. In addition, similar Cotton effects at 212, 220, and $237 \mathrm{~nm}$ in the ECD spectra (Figure 6) of $\mathbf{6}$ suggested that $\mathbf{6}$ and $\mathbf{1 7}$ had the same counterpart absolute configurations. Thus, the absolute configuration of 6 was assigned as $(2 S, 13 S)$, and it was elucidated as 6-ethoxy-aspamide F.

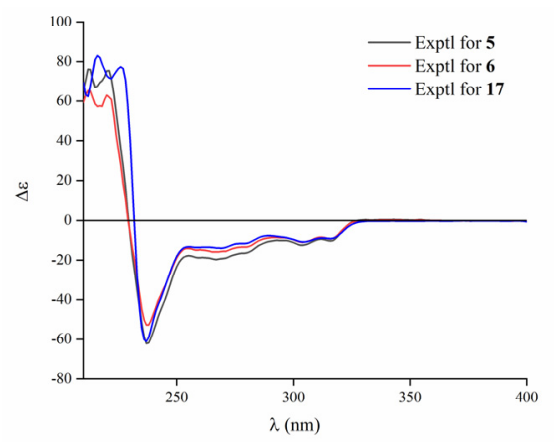

Figure 6. Experimental ECD spectra of 5, 6, and 17.

All isolated compounds were tested for their anti-inflammatory activities in P. acnes-induced THP-1 cells; unfortunately, none of the compounds showed moderate anti-inflammatory properties. Aiming to give our contribution to the COVID-19 research, all compounds were selected for the virtual screening on the 3CL hydrolase (Mpro) of SARS-CoV-2, which had been exploited as a potential drug target to fight COVID-19 [27]. The docking scores of compounds 1-2, 5, 6, 8 and 17 were top among all screened molecules (docking scores: $-5.389,-4.772,-5.146,-4.962,-5.158$ ), and the score of ritonavir [36] (a potent inhibitor in vitro of human immunodeficiency virus type 1 protease) was -7.039, which suggested that these compounds may be helpful in fighting COVID-19 after further studies.

\section{Materials and Methods}

\subsection{General Experimental Procedures}

Optical rotations were recorded on a JASCO P-1020 polarimeter (JASCO Corporation, Tokyo, Japan) in $\mathrm{MeOH}$ at $25^{\circ} \mathrm{C}$. UV spectra were measured using a Shimadzu UV-1800 spectrophotometer (Shimadzu Corporation, Tokyo, Japan). High-resolution electrospray ionization (HR-ESI-MS) were obtained with an Agilent 6529B Q-TOF instrument (Agilent Technologies, Santa Clara, CA, USA). ECD spectra were carried out with Chirascan circular dichroism spectrometers (Applied Photophysics Ltd., Leatherhead, UK). Both 1D and 2D NMR spectra were acquired on a Bruker AVIII-400 and Bruker AVIII-600 NMR spectrometers with tetramethylsilane (TMS) as an internal standard (Bruker, Karlsruhe, Germany). Preparative high-performance liquid chromatography (Pre-HPLC) was performed utilizing a Shimadzu LC-20 system (Shimadzu, Tokyo, Japan) equipped with a Shim-pack RP-C18 column $\left(20 \times 250 \mathrm{~mm}\right.$ i.d., $10 \mu \mathrm{m}$, Shimadzu, Tokyo, Japan) with a flow rate at $10 \mathrm{~mL} / \mathrm{min}$ at $25^{\circ} \mathrm{C}$, which was recorded by a binary channel UV detector at $210 \mathrm{~nm}$ and $254 \mathrm{~nm}$. The analytical chiral HPLC used was a JASCO LC-2000 system equipped with a Daicel Chiralpak AD-H column $(4.6 \mathrm{~mm} \times 250 \mathrm{~mm}$, $5 \mu \mathrm{m})$ and a CD-2095 chiral detector at $280 \mathrm{~nm}$. The mobile phase was $n$-hexane/isopropanol (80:20, $v / v)$ used at a flow rate of $0.5 \mathrm{~mL} / \mathrm{min}$. Column chromatography (CC) was performed with silica

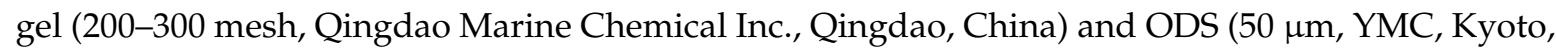
Japan) on a Flash Chromatograph System (SepaBen machine, Santai Technologies, Changzhou, China). Thin-layer chromatography (TLC) was performed using precoated silica gel GF254 plates (Qingdao Marine Chemical Inc., Qingdao, China). 


\subsection{Fungal Material}

The endophytic DY180635 was isolated from a sample of crab (Chiromantes haematocheir), which was collected from the intertidal zone of Zhoushan, Zhejiang, China, in June 2018. It was incubated on a potato dextrose agar (PDA) plate at $28{ }^{\circ} \mathrm{C}$. The strain DY180635 was identified using ITS rDNA sequence analysis by RuiDi (Shanghai, China) and its DNA sequence using BLAST was compared to the GenBank data. The result of BLAST searching was closest to that of Aspergillus versicolor NRRL 238 (GenBank accession number NG_067623) with 99\% sequence identity. The nucleotide sequences of the ITS gene (accession number MT361076) of A. versicolor DY180635 were deposited in GenBank. A reference culture is stored in State Key Laboratory of Bioreactor Engineering laboratory of Shanghai at $-80^{\circ} \mathrm{C}$.

\subsection{Fermentation, Extraction, and Isolation}

The fungus was incubated on potato dextrose agar (PDA) medium at $28^{\circ} \mathrm{C}$ for approximately 2-3 days; then it was cut into three agar pieces (nearly the size of $0.5 \times 0.5 \times 0.5 \mathrm{~cm}$ ) and transferred into a $500 \mathrm{~mL}$ Erlenmeyer flask, containing $200 \mathrm{~mL}$ of potato dextrose broth (PDB). The flasks were cultured for 2 days at $28^{\circ} \mathrm{C}$ on a rotary shaker at $180 \mathrm{rpm}$ for inoculation. The seed cultures were added to the $200 \times 1 \mathrm{~L}$ flasks containing rice medium ( $110 \mathrm{~g}$ rice, $120 \mathrm{~mL}$ deionized water), which was previously sterilized at $121^{\circ} \mathrm{C}$ for $25 \mathrm{~min}$. All flasks were incubated at $28^{\circ} \mathrm{C}$ for four weeks.

Following incubation, the solid rice cultures were extracted three times by EtOAc to give a crude extract (489.0 g); the crude extract was suspended in water and then partitioned with EtOAc to give an EtOAc soluble fraction ( $185.2 \mathrm{~g}$ ) after the solvent was removed to dryness under reduced pressure. The EtOAc fraction was further separated on macroporous adsorbent resin with a stepped gradient elution with $\mathrm{EtOH}-\mathrm{H}_{2} \mathrm{O}$ (30, 50, 70 and 100\%). The 50\% fraction was sequentially separated by silica gel with petroleum ether-EtOAc (5:1 to 0:1) to give four subfractions (A-D) using the TLC. The subfraction $\mathrm{B}(9.0 \mathrm{~g})$ was sequentially loaded onto silica gel CC (petroleum ether-EtOAc, 5:1) and preparative HPLC ( $\left.\mathrm{MeCN}-\mathrm{H}_{2} \mathrm{O}, 50: 50,10.0 \mathrm{~mL} / \mathrm{min}\right)$ to yield compounds $1\left(10.4 \mathrm{mg}, t_{\mathrm{R}} 34.9 \mathrm{~min}\right), 2\left(6.4 \mathrm{mg}, t_{\mathrm{R}} 27.1 \mathrm{~min}\right)$, $4\left(5.9 \mathrm{mg}, t_{\mathrm{R}} 33.5 \mathrm{~min}\right)$, and $6\left(8.7 \mathrm{mg}, t_{\mathrm{R}} 23.2 \mathrm{~min}\right)$. Subfraction $\mathrm{C}(15.0 \mathrm{~g})$ was further separated by an ODS column ( $\mathrm{MeCN}-\mathrm{H}_{2} \mathrm{O}, 40: 60$ ) and repeated preparative HPLC with $\mathrm{MeCN}_{-} \mathrm{H}_{2} \mathrm{O}$ (50:50, $10 \mathrm{~mL} / \mathrm{min}$ ) to give compounds 3 ( $\left.4.6 \mathrm{mg}, t_{\mathrm{R}} 8.8 \mathrm{~min}\right)$ and $\mathbf{5}\left(4.7 \mathrm{mg}, t_{\mathrm{R}} 17.1 \mathrm{~min}\right)$.

Aspamide A (1): yellowish powder; $[\alpha]_{\mathrm{D}}^{25}+120.0$ (c 0.05, MeOH); ECD (5 mg/L, MeOH) $\lambda_{\max }(\Delta \varepsilon) 212$ (92.18), 245 (-41.48) 335 (19.29) nm; UV (MeOH) $\lambda_{\max }(\log \varepsilon) 200$ (6.13), 224 (6.13), 284 (5.46), 341 (5.68) $\mathrm{nm} ;{ }^{1} \mathrm{H}$ and ${ }^{13} \mathrm{C}$ NMR (DMSO- $d_{6}$ ), see Table 1 ; positive HR-ESI-MS $m / z 394.2117[\mathrm{M}+\mathrm{H}]{ }^{+}$, (calcd. for $\mathrm{C}_{23} \mathrm{H}_{28} \mathrm{~N}_{3} \mathrm{O}_{3}, 394.2125$ ).

Aspamide B (2): yellowish powder; $[\alpha]_{\mathrm{D}}^{25}+112.0\left(\right.$ c 0.05, MeOH); $\mathrm{ECD}(5 \mathrm{mg} / \mathrm{L}, \mathrm{MeOH}) \lambda_{\max }(\Delta \varepsilon) 212$ (83.31), 261 (-37.91), 340 (20.41) nm; UV (MeOH) $\lambda_{\max }(\log \varepsilon) 200$ (6.18), 224 (6.18), 283 (5.45), 345 (5.73) $\mathrm{nm} ;{ }^{1} \mathrm{H}$ and ${ }^{13} \mathrm{C}$ NMR (DMSO- $d_{6}$ ), see Table 1; positive HR-ESI-MS $m / z 394.2120[\mathrm{M}+\mathrm{H}]^{+}$, (calcd. for $\left.\mathrm{C}_{23} \mathrm{H}_{28} \mathrm{~N}_{3} \mathrm{O}_{3}, 394.2125\right)$.

Aspamide C (3): yellowish powder; $[\alpha]_{\mathrm{D}}^{25}+125.0$ (c 0.05, MeOH); ECD (5 mg/L, MeOH) $\lambda_{\max }(\Delta \varepsilon) 211$ (103.75), 255 (-44.38), 334 (24.79) nm; UV (MeOH) $\lambda_{\max }(\log \varepsilon) 200$ (6.20), 224 (6.19), 284 (5.56), 337 (5.75) $\mathrm{nm} ;{ }^{1} \mathrm{H}$ and ${ }^{13} \mathrm{C}$ NMR (DMSO- $d_{6}$ ), see Table 1; positive HR-ESI-MS $m / z 366.1807[\mathrm{M}+\mathrm{H}]^{+}$, (calcd. for $\mathrm{C}_{21} \mathrm{H}_{24} \mathrm{~N}_{3} \mathrm{O}_{3}, 366.1812$ ).

( \pm )-Aspamide D (4): colorless gum; $[\alpha]_{\mathrm{D}}^{25}+5.0\left(\right.$ c 0.05, MeOH); UV (MeOH) $\lambda_{\max }(\log \varepsilon) 200$ (6.07), 224 (6.06), 283 (5.33), 346 (5.60) nm; ${ }^{1} \mathrm{H}$ and ${ }^{13} \mathrm{C}$ NMR (DMSO- $d_{6}$ ), see Table 2; positive HR-ESI-MS $\mathrm{m} / \mathrm{z}$ $394.2122[\mathrm{M}+\mathrm{H}]^{+}$, (calcd. for $\left.\mathrm{C}_{23} \mathrm{H}_{28} \mathrm{~N}_{3} \mathrm{O}_{3}, 394.2125\right)$.

Aspamide F (5): brown powder; $[\alpha]_{\mathrm{D}}^{25}+40.0$ (c 0.05, MeOH); ECD $(5 \mathrm{mg} / \mathrm{L}, \mathrm{MeOH}) \lambda_{\max }(\Delta \varepsilon)$ 212 (65.33), 220 (62.98), 237 (-52.79) nm; UV (MeOH) $\lambda_{\max }(\log \varepsilon) 206$ (5.95), 224 (6.15), 270 (5.25), 
278 (5.23) nm; ${ }^{1} \mathrm{H}$ and ${ }^{13} \mathrm{C}$ NMR $\left(\mathrm{CDCl}_{3}\right)$, see Table 2; positive HR-ESI-MS $\mathrm{m} / z 336.1336[\mathrm{M}+\mathrm{H}]^{+}$, (calcd. for $\mathrm{C}_{19} \mathrm{H}_{18} \mathrm{~N}_{3} \mathrm{O}_{3}, 336.1343$ ).

Aspamide G (6): brown powder; $[\alpha]_{\mathrm{D}}^{25}+56.0(c 0.05, \mathrm{MeOH}) ; \mathrm{ECD}(5 \mathrm{mg} / \mathrm{L}, \mathrm{MeOH}) \lambda_{\max }(\Delta \varepsilon) 212$ (76.04), 221 (75.42), 237 (-62.18) nm; UV (MeOH) $\lambda_{\max }(\log \varepsilon) 205$ (5.92), 222 (5.88), 270 (5.16), 278 (5.13) $\mathrm{nm} ;{ }^{1} \mathrm{H}$ and ${ }^{13} \mathrm{C}$ NMR $\left(\mathrm{CDCl}_{3}\right)$, see Table 2; positive HR-ESI-MS $\mathrm{m} / z 350.1498[\mathrm{M}+\mathrm{H}]^{+}$, (calcd. for $\left.\mathrm{C}_{20} \mathrm{H}_{20} \mathrm{~N}_{3} \mathrm{O}_{3}, 350.1499\right)$.

\subsection{ECD Calculation}

The relative configuration of $\mathbf{1}$ was established initially according to its ROESY NMR spectra. Monte Carlo conformational searches were carried out by means of the Spartan's 14 software using the Merck molecular force field (MMFF). The conformers with Boltzmann population of over $1 \%$ were chosen for ECD calculations, and then the conformers were initially optimized at the B3LYP/6-31G $(d, p)$ level in gas. The theoretical calculation of ECD was conducted in $\mathrm{MeOH}$ using Time-dependent Density functional theory (TD-DFT) at the B3LYP/6-31+G(d,p) level for all conformers. Rotatory strengths for a total of 100 excited states were calculated. ECD spectra were generated using the program SpecDis 1.6 (University of Würzburg, Würzburg, Germany) and GraphPad Prism 5 (University of California San Diego, USA) from dipole-length rotational strengths by applying Gaussian band shapes with sigma $=0.3 \mathrm{eV}$. And UV-shift values of all configurations were $-10 \mathrm{~nm}$. The spectra of enantiomers were produced directly by mirror inversions.

\subsection{Virtual Screening Against COVID-19 Main Protease}

\subsubsection{Protein and Ligand Preparation}

The 3CL hydrolase (Mpro) of SARS-CoV-2 had been exploited as a potential drug target to fight COVID-19 [27]. Thus, the virtual screening was conducted by using the SARS-CoV-2 enzyme (PDB ID 6LU7) obtained from the Protein Data Bank (PDB, http://www.rcsb.org/pdb), and the structure was optimized by using the protein preparation wizard module in Maestro software package (Schrodinger LLC, NY, USA). Specifically, the water and heteroatom were removed, the polar hydrogens were added to the protein to the protonation state, the entire structure was assumed as a neutral $\mathrm{pH}$, and the energy of the structure was minimized by using an OPLS2005 force field. The docking grid of $20 \AA$ size was generated over the co-crystallized ligand. All compounds 1-17 were implemented by Ligprep software, and the structure energy was minimized using OPL2005 force field.

\subsubsection{Virtual Screening}

Virtual screening was performed by the Schrodinger glide docking module, and the standardprecision (SP) docking was designated to get accurate results [37]. The results were measured by docking score, and only the compounds with scores in the top half were subjected to the extra-precision (XP) docking.

\subsection{Cell Culture and Cell Viability Assay}

The human monocytic cell line, THP-1 (Cell Bank of China Science Academy, Shanghai, China) and P. acnes (ATCC6919, Xiangfu biotech, Shanghai, China), were used for the anti-inflammatory assay. THP-1 cells were cultured in RPMI1640 medium with 10\% fetal bovine serum (FBS, Gibco, NY, USA) in a humidified incubator $\left(37^{\circ} \mathrm{C}, 5 \% \mathrm{CO}_{2}\right)$. P. acnes bacteria were incubated in Cooked Meat Medium, containing cooked beef granules (Rishui biotechnology, Qingdao, China) in an anaerobic environment. The THP-1 cells were stimulated by the P. acnes, which was harvested at the exponential phase. The viability of THP-1 cells was evaluated by the MTT assay, specifically, seeding the THP-1 cells in 96-well plates at a density of $2 \times 10^{5}$ cells/well and treated with serially diluted compounds for $36 \mathrm{~h}\left(37^{\circ} \mathrm{C}, 5 \% \mathrm{CO}_{2}\right)$. After that, we added $20 \mu \mathrm{L}$ MTT regent $(5 \mathrm{mg} / \mathrm{mL}$, Genetimes Technology Inc., 
Shanghai, China) to each well and incubated the samples at $37^{\circ} \mathrm{C}$ for $4 \mathrm{~h}$. Removing the supernatant, the formazan crystals were fully solubilized in DMSO $(150 \mu \mathrm{L})$, and the absorbance was measured at $570 \mathrm{~nm}$ and $630 \mathrm{~nm}$.

\section{Conclusions}

Chemical investigation of a marine-derived fungus Aspergillus versicolor DY180635 led to the isolation and identification of four new IDPKs, aspamides A-E (1-4) and two new DPKs, aspamides F-G (5-6), along with 11 known diketopiperazines and intermediates. Further chiral high-performance liquid chromatography resolution gave enantiomers (+)- and (-)-4, respectively. The structures and absolute configurations of compounds 1-6 were determined by the comprehensive analyses of NMR, HRESIMS, and ECD calculation. Compounds 1-17 were selected for the virtual screening on the 3CL hydrolase (Mpro) of SARS-CoV-2, and compounds 1-2, 5, 6, 8 and 17 possessed top docking scores and thus may be helpful in fighting COVID-19 after further studies.

Supplementary Materials: The following are available online at: http://www.mdpi.com/1660-3397/18/7/338/s1, Figures S1-S46: ${ }^{1} \mathrm{H},{ }^{13} \mathrm{C}$, HSQC, HMBC, ROESY, UV, ECD, and HRESIMS spectra of the new compounds 1-6, Tables S1-S6: Computational data of $\mathbf{1}$ and $\mathbf{4}$.

Author Contributions: Y.D. performed the isolation, purification and identification of all compounds. X.Z. tested the anti-inflammatory activities. L.H. and M.Z. supervised the laboratory work. Q.H. edited the manuscript. F.A. supervised the laboratory work, designed the experiments and edited the manuscript. All authors have read and agree to the published version of the manuscript.

Funding: This work was funded by the National Key R\&D Program of China (2018YFC1706200, 2019YFC0312504), and the National Natural Science Foundation of China $(41876189,81703388)$. This work was also supported by State Key Laboratory of Bioreactor Engineering. Authors thank Prof. Lixin Zhang (State Key Laboratory of Bioreactor Engineering, East China University of Science and Technology) for assistance in the virtual screening on the Mpro of SARS-CoV-2.

Conflicts of Interest: The authors declare no conflict of interest.

\section{References}

1. Strobel, G.; Daisy, B.; Castillo, U.; Harper, J. Natural products from endophytic microorganisms. J. Nat. Prod. 2004, 67, 257-268. [CrossRef]

2. Blunt, J.W.; Copp, B.R.; Keyzers, R.A.; Munro, M.H.G.; Prinsep, M.R. Marine natural products. Nat. Prod. Rep. 2017, 34, 235-294. [CrossRef] [PubMed]

3. Bugni, T.S.; Ireland, C.M. Marine-derived fungi: A chemically and biologically diverse group of microorganisms. Nat. Prod. Rep. 2004, 21, 143-163. [CrossRef]

4. Ma, Y.M.; Liang, X.A.; Kong, Y.; Jia, B. Structural diversity and biological activities of indole diketopiperazine alkaloids from fungi. J. Agric. Food Chem. 2016, 64, 6659-6671. [CrossRef] [PubMed]

5. Borthwick, A.D. 2,5-Diketopiperazines: Synthesis, reactions, medicinal chemistry, and bioactive natural products. Chem. Rev. 2012, 112, 3641-3716. [CrossRef] [PubMed]

6. Wang, W.L.; Lu, Z.Y.; Tao, H.W.; Zhu, T.J.; Fang, Y.C.; Gu, Q.Q.; Zhu, W.M. Isoechinulin-type alkaloids, variecolorins A-L, from halotolerant Aspergillus variecolor. J. Nat. Prod. 2007, 70, 1558-1564. [CrossRef]

7. Cai, S.X.; Sun, S.W.; Peng, J.X.; Kong, X.L.; Zhou, H.N.; Zhu, T.J.; Gu, Q.Q.; Li, D.H. Okaramines S-U, three new indole diketopiperazine alkaloids from Aspergillus taichungensis ZHN-7-07. Tetrahedron 2015, 71, 3715-3719. [CrossRef]

8. Wang, F.Z.; Fang, Y.C.; Zhu, T.J.; Zhang, M.; Lin, A.Q.; Gu, Q.Q.; Zhu, W.M. Seven new prenylated indole diketopiperazine alkaloids from holothurian-derived fungus Aspergillus fumigatus. Tetrahedron 2008, 64, 7986-7991. [CrossRef]

9. Tsukamoto, S.; Kato, H.; Samizo, M.; Nojiri, Y.; Onuki, H.; Hirota, H.; Ohta, T. Notoamides F-K, prenylated indole alkaloids isolated from a marine-derived Aspergillus sp. J. Nat. Prod. 2008, 71, 2064-2067. [CrossRef]

10. Kozlovsky, A.G.; Vinokurova, N.G.; Adanin, V.M. Diketopiperazine alkaloids from the fungus Penicillium piscarium westling. Appl. Biochem. Microbiol. 2000, 36, 271-275. [CrossRef] 
11. Ravikanth, V.; Niranjan Reddy, V.L.; Ramesh, P.; Prabhakar Rao, T.; Diwan, P.V.; Khar, A.; Venkateswarlu, Y. An immunosuppressive tryptophan-derived alkaloid from Lepidagathis cristata. Phytochemistry 2001, 58, 1263-1266. [CrossRef]

12. Fujimoto, H.; Sumino, M.; Okuyama, E.; Ishibashi, M. Immunomodulatory constituents from an Ascomycete. J. Nat. Prod. 2004, 67, 98-102. [CrossRef]

13. Kuramochi, K.; Ohnishi, K.; Fujieda, S.; Nakajima, M.; Saitoh, Y.; Watanabe, N.; Takeuchi, T.; Nakazaki, A.; Sugawara, F.; Arai, T.; et al. Synthesis and biological activities of neoechinulin A derivatives: New aspects of structure-activity relationships for neoechinulin A. Chem. Pharm. Bull. 2008, 56, 1738-1743. [CrossRef] [PubMed]

14. Fan, Z.; Sun, Z.H.; Liu, Z.; Chen, Y.C.; Liu, H.X.; Li, H.H.; Zhang, W.M. Dichotocejpins A-C: New diketopiperazines from a deep-sea-derived fungus Dichotomomyces cejpii FS110. Mar. Drugs 2016, 14, 1-9. [CrossRef] [PubMed]

15. Mohanlal, R.W.; Lloyd, K.; Huang, L. Plinabulin, a novel small molecule clinical stage IO agent with anti-cancer activity, to prevent chemo-induced neutropenia and immune related AEs. J. Clin. Oncol. 2018, 36, 126. [CrossRef]

16. Gomes, N.G.M.; Lefranc, F.; Kijjoa, A.; Kiss, R. Can some marine-ferived fungal metabolites become actual anticancer agents? Mar. Drugs 2015, 13, 3950-3991. [CrossRef]

17. Geiger, W.B.; Conn, J.E.; Waksman, S.A. Chaetomin, a new antibiotic substance produced by Chaetomium cochliodes: II. Isolation and Concentration. J. Bacteriol. 1944, 48, 531-536. [CrossRef]

18. Tian, W.; Sun, C.; Zheng, M.; Harmer, J.R.; Yu, M.; Zhang, Y.; Peng, H.; Zhu, D.; Deng, Z.; Chen, S.L.; et al. Efficient biosynthesis of heterodimeric $C^{3}$-aryl pyrroloindoline alkaloids. Nat. Commun. 2018, 9, 4428. [CrossRef]

19. Ye, Y.; Du, L.; Zhang, X.W.; Newmister, S.A.; McCauley, M.; Alegre-Requena, J.V.; Zhang, W.; Mu, S.; Minami, A.; Fraley, A.E.; et al. Fungal-derived brevianamide assembly by a stereoselective semipinacolase. Nat. Catal. 2020. [CrossRef]

20. Song, F.; Liu, X.; Guo, H.; Ren, B.; Chen, C.; Piggott, A.M.; Yu, K.; Gao, H.; Wang, Q.; Liu, M.; et al. Brevianamides with antitubercular potential from a marine-derived isolate of Aspergillus versicolor. Org. Lett. 2012, 14, 4770-4773. [CrossRef]

21. James, E.D.; Knuckley, B.; Alqahtani, N.; Porwal, S.; Ban, J.; Karty, J.A.; Viswanathan, R.; Lane, A.L. Two distinct cyclodipeptide synthases from a marine Actinomycete catalyze biosynthesis of the same diketopiperazine natural product. ACS Synth. Biol. 2016, 5, 547-553. [CrossRef] [PubMed]

22. Haines, B.E.; Nelson, B.M.; Grandner, J.M.; Kim, J.; Houk, K.N.; Movassaghi, M.; Musaev, D.G. Mechanism of permanganate-promoted dihydroxylation of complex diketopiperazines: Critical roles of counter-cation and ion-pairing. J. Am. Chem. Soc. 2018, 140, 13375-13386. [CrossRef]

23. Ding, Y.; An, F.L.; Zhu, X.J.; Yu, H.Y.; Hao, L.L.; Lu, Y.H. Curdepsidones B-G, six depsidones with anti-inflammatory activities from the marine-derived fungus Curvularia sp. IFB-Z10. Mar. Drugs 2019, 17, 266. [CrossRef]

24. Liu, W.H.; Ding, Y.; Ji, X.; An, F.L.; Lu, Y.H. Curvulaide A, a bicyclic polyketide with anti-anaerobic bacteria activity from marine-derived Curvularia sp. J. Antibiot. 2019, 72, 111-113. [CrossRef]

25. Guo, M.M.; Lu, Y.; Yang, J.P.; Zhao, X.; Lu, Y.H. Inhibitory effects of Schisandra chinensis extract on acne-related inflammation and UVB-induced photoageing. Pharm. Biol. 2016, 54, 2987-2994. [CrossRef] [PubMed]

26. Dillman, R.L.; Cardellina, J.H. Aromatic secondary metabolites from the sponge Tedania ignis. J. Nat. Prod. 1991, 54, 1056-1061. [CrossRef]

27. Jin, Z.M.; Du, X.Y.; Xu, Y.C.; Deng, Y.Q.; Liu, M.Q.; Zhao, Y.; Zhang, B.; Li, X.F.; Zhang, L.K.; Peng, C.F.; et al. Structure of Mpro from COVID-19 virus and discovery of its inhibitors. Nature 2020, 582, 289-293. [CrossRef] [PubMed]

28. Li, G.Y.; Yang, T.; Luo, Y.G.; Chen, X.Z.; Fang, D.M.; Zhang, G.L. Brevianamide J, a new indole alkaloid dimer from fungus Aspergillus versicolor. Org. Lett. 2009, 11, 3714-3717. [CrossRef]

29. Li, G.Y.; Li, L.M.; Yang, T.; Chen, X.Z.; Fang, D.M.; Zhang, G.L. Four new alkaloids, brevianamides O-R, from the fungus Aspergillus versicolor. Helv. Chim. Acta 2010, 93, 2075-2080. [CrossRef]

30. Liu, Y.X.; Ma, S.G.; Wang, X.J.; Zhao, N.; Qu, J.; Yu, S.S.; Dai, J.G.; Wang, Y.H.; Si, Y.K. Diketopiperazine alkaloids produced by the endophytic fungus Aspergillus fumigatus from the Stem of Erythrophloeum fordii Olıv. Helv. Chim. Acta 2012, 95, 1401-1408. [CrossRef] 
31. Schkeryantz, J.M.; Woo, J.C.G.; Siliphaivanh, P.; Depew, K.M.; Danishefsky, S.J. Total synthesis of gypsetin, deoxybrevianamide E, brevianamide E, and tryprostatin B: Novel constructions of 2,3-disubstituted indoles. J. Am. Chem. Soc. 1999, 121, 11964-11975. [CrossRef]

32. Sanz-Cervera, J.F.; Stocking, E.M.; Usui, T.; Osada, H.; Williams, R.M. Synthesis and evaluation of microtubule assembly inhibition and cytotoxicity of prenylated derivatives of cyclo-L-Trp-L-Pro. Bioorg. Med. Chem. 2000, 8, 2407-2415. [CrossRef]

33. May Zin, W.W.; Buttachon, S.; Dethoup, T.; Pereira, J.A.; Gales, L.; Inácio, Â.; Costa, P.M.; Lee, M.; Sekeroglu, N.; Silva, A.M.S.; et al. Antibacterial and antibiofilm activities of the metabolites isolated from the culture of the mangrove-derived endophytic fungus Eurotium chevalieri KUFA 0006. Phytochemistry 2017, 141, 86-97. [CrossRef] [PubMed]

34. Pirrung, M.C.; Fujita, K.; Park, K. Organometallic routes to 2,5-dihydroxy-3-(indol-3-yl)-benzoquinones. Synthesis of demethylasterriquinone B4. J. Org. Chem. 2005, 70, 2537-2542. [CrossRef]

35. Liu, W.; Wang, L.P.; Wang, B.; Xu, Y.C.; Zhu, G.L.; Lan, M.M.; Zhu, W.M.; Sun, K.L. Diketopiperazine and diphenylether derivatives from marine algae-derived Aspergillus versicolor OUCMDZ-2738 by epigenetic activation. Mar. Drugs 2019, 17, 6. [CrossRef]

36. Markowitz, M.; Saag, M.; Powderly, W.G.; Hurley, A.M.; Hsu, A.; Valdes, J.M.; Henry, D.; Sattler, F.; La Marca, A.; Leonard, J.M.; et al. A preliminary study of ritonavir, an inhibitor of HIV-1 protease, to treat HIV-1 infection. N. Engl. J. Med. 1995, 333, 1534-1539. [CrossRef]

37. Halgren, T.A.; Murphy, R.B.; Friesner, R.A.; Beard, H.S.; Frye, L.L.; Pollard, W.T.; Banks, J.L. Glide: A new approach for rapid, accurate docking and scoring. 2. Enrichment factors in database screening. J. Med. Chem 2004, 47, 1750-1759. [CrossRef]

(C) 2020 by the authors. Licensee MDPI, Basel, Switzerland. This article is an open access article distributed under the terms and conditions of the Creative Commons Attribution (CC BY) license (http://creativecommons.org/licenses/by/4.0/). 